\title{
REPRESENTATIONS OF POWER
}

IN MAYOMBE: “MEN WILL BE PRISONERS

OF THE STRUCTURES THEY WILL HAVE CREATED"1

\section{Carolina Bezerra Machado²}

I suffered colonialism in the flesh. My father was killed by the tugas. How can I bear to see people who have not suffered now commanding us, how can they know what we need? It is against this injustice that we have to fight: that the real children of the people, the genuine ones, take things in hand (Pepetela 2013, 47).

\section{Introduction}

The passage highlighted above, referring to the novel Mayombe, in which the character "Milagre" assumes the first person of the narrative, is fundamental to rethink the process of creating the state in Angola, based on the internal political disputes that still occurred during the colonial period and that extended into post-independence. The controversies about Angolan nationalism and identity were woven from different interests among the groups that disputed political power, which in their way, supported on the disqualification of others, proclaimed themselves as genuinely Angolan. The policy of favoritism, based on privileges for the closest ones, cases of corruption, ideological differences, and regional disputes that will characterize post-independence in Angola, were also already present in the anti-colonial struggle, despite of there seeming to be plenty of time available to fix them and maintain the dream of a more egalitarian and democratic society.

I This article is part of a larger research that resulted in the author's PhD thesis.

2 Department of History, Universidade do Estado do Rio de Janeiro. Rio de Janeiro, Brazil.

E-mail: lowbezerra@gmail.com 
Written during the guerrilla war, but published only in I980, a period in which there was a political discourse of national mobilization, from the defense of the construction of a "New Man", the book also brings an enriching debate about the ethnic and racial fissures that existed within the Popular Movement for the Liberation of Angola (MPLA, in portuguese), as well as in Angolan society. As the proposal here is to address the power relations and micro-powers that have been built between the state and the Angolan society in the post-independence through the reading of Mayombe, it is valid to return to these issues. It is noted how much ethnic and racial tensions remained in the political arena after the country's independence and contributed, in a significant way, to the political structuring of Angola, guided by the MPLA, which sought to detach itself from these debates, diminishing them and treating them on the margins. After all, the tension surrounding this discourse contributed to the political escalation among nationalist movements and to the mobilization for civil war, which is inseparable from the process of formation of the post-colonial Angolan state.

In understanding that, like the nation, the construction of a state should not be seen as something natural, but as something artificial and susceptible to political disputes, it is fundamental to focus on the formation of the Angolan state after independence, as well as the main actors involved in this process, the limits of this new state, the colonial permanences and the role played by the MPLA in the country's politics. The end of colonialism in Angola did not bring the desired peace, but a new political instability with a scenario of war between the main nationalist movements that disputed power. In this sense, it is important to highlight how much ethnic and racial disputes, as well as the different social and economic components, still created under the colonial yoke, remained and contributed to the state's weaknesses. For Bittencourt, this "inability to unify nationalist forces" is related to the "historical contexts built on colonial experience", fragmented and unequal (Bittencourt 20I5, 23I).

Taking these issues into consideration, we should note the social tensions that characterized the formation of the state after the independence process, since the complexities stemming from the historical differences of the social groups that composed Angolan society, from their trajectories and experiences in different socio-cultural spaces, contributed to the coexistence of different national projects. In view of this, disputes over politics will also be permeated by conflicts that were part of the formation of the Angolan state. In a recent research, Catarina Antunes (2009) proposes to analyze how the MPLA has consolidated itself in the government, even in the midst of different existing political projects, both internally and by the opposition. To do so, she reflects on the authoritarian 
character that the movement has come to represent, as constant threats have come to be present. However, to reflect on the contradictions between Angola's political relations, an analysis of the colonial state is also employed to understand the continuities that existed in the post-colonial period, when differences remained and opened space for new conflicts (Antunes 2009, 67-69).

\section{Pepetela's novels and trajectory, and the politics of Angola}

Thus, the choice for the analysis of power relations in Angola after independence based on Mayombe, a novel produced during the guerrilla war in Cabinda in I97I, thus still written during the colonial period, is justified by the debate on politics in Angola that already accompanied the work. The reflections, as well as the disputes between the guerrilla-characters in the book, point to the construction of a political reality that will be fundamental to understand the relations that are established in the post-independence. Besides, we should still be attentive to the possible writings and/or rewrites that the book may contain, since its publication took place only in I980, a period of a great political clash among the groups that rivaled power in the country. As Fábio Baqueiro (Maria 20II) points out, in Mayombe several delicate themes, in which the critical tone is high, will be worked on, as much as we cannot point to a rupture, because the defense of a reconstruction project still ruled by the MPLA is evident. In an interview to the historian, Adolfo Maria recalls that he was one of the first readers of the novel:

Mandatorily, I was. I was because we were very good friends, and I even criticized it, I read Mayombe typed on the machine, which was writing at that time. [...]

And more than this, Mayombe, when he went East, he left it with me in storage. When I arrived in Luanda - [...] we were in opposite camps, but we never stopped having relations - he asked me: "do you still have it? because of mine...I lost mine". And I gave it to him. [...]

And I would like to have that manuscript today - to compare it with what was published. Because I read the Mayombe, this printed Mayombe has less strength than the manuscript I read. In the conflicts of people etc., in the conflicts of the soul, of spirit, [...] the plot was more complicated and, let's say, the criticism of the environment and the context was more explicit. [...] I got the feeling, and then said: "What a pity if I had the manuscript, I could compare". But that's it, he went to get it, and it was his, and I gave it. "Have you brought it? Did you keep it?" - "I brought it.” - "Ah!” Ready (Maria, Adolfo. In.: Figueiredo, F. B. 20I2). 
From the interview comes a questioning about the possible external interferences that could have led to a rewriting or a readaptation of some key moments of the novel. In any case, as the writer has already pointed out, the political criticisms contained in it started from a militant who saw the internal problems and indicated the existing fails and contradictions that should receive more attention. The choice to address some of the delicate issues of Angolan politics, which preceded some of the political conflicts that took place in the country after independence, generated questions, sometimes answered in interviews, in which the writer takes up the reality of neighboring African countries, whose independence process did not guarantee political stability, but rather gave rise to new disputes for power to justify some of the issues addressed in the work. In 20I6, Pepetela was at the Universidade Federal do Rio de Janeiro (UFRJ) at the invitation of the African Literature Sector of the University's Department of Vernacular Letters. At the meeting, after being asked about the criticism that had already appeared in Mayombe about the formation of the Angolan state in the post-independence, he replied that it would be easy to predict the bureaucratization of the country when taking into account the experience of the African countries under one-party systems, even more so that this experience was based on the tradition of the socialist countries of Europe. For Pepetela, within that context of independence, a democratic political way out would be unfeasible ${ }^{3}$.

However, it is not appropriate here to debate whether a subject was written in I971 or I980, but rather to understand the impact that such a work has on the disputes over politics, as well as the extent to which it contributes since its publication to an analysis of power relations in Angola after independence. By reading Mayombe we are involved in a political reality of denouncing the approximations between "tribalism" and power struggles, as well as between ethnic issues and the politics of favoritism that already existed in the woods, which will be one of the main problems faced later, hence the importance of analysis. These issues appear as obstacles to nation-building, but also to the strengthening of the state. They are criticisms of a political system that was already born distorted, with internal conflicts that will go beyond this moment and will be present in the I980s, reaching still the disputes between the movements.

On the other hand, we can also recognize the didactic sense of criticism and the defense for the internal renewal of the movement as political opponents of the MPLA are disqualified and the defense of the construction

3 Pepetela in lecture at the Federal University of Rio de Janeiro (UFRJ) on o6/2I/20I6. 
of a New Man is highlighted 4 . But one of the debates that must be deepened here, and for this, it is necessary to go back to the novel, is the already existing concern with the authoritarianism of a political system, that appears in some characters, although the internal reformulations proposed by Pepetela throughout the narrative are also evident, which must be thought of in dialogue with the moment of publication, especially when noticing moments of reflection on the political structure of the movement from passages that seem to be a reference to political decisions of an authoritarian nature in the face of political dissidences that at the time of publication were already a reality, such as the Revolt of the East (1972), the Active Revolt (I974) and the Nitista Movement (I977).

At various times in the novel, politics are widely debated. For a few pages, we are involved in the political relations of the militants through their ambiguities, yearnings, and contradictions. From a disagreement that arose between Commander Sem Medo, the protagonist of the book, and the Political Commissioner, another important character and main interlocutor of Sem Medo, the reflections on the political are high. Everything begins when the Commissioner calls the Commander's attention in front of the other guerrilla fighters, causing a malaise for breaking the hierarchy patterns and turning against the attitude of a superior. The Commissioner's apology leads to a series of debates in which Sem Medo defends the freedom to criticize as well as the democratization of the political environment: "- The guerrillas must get used to hearing those responsible criticize each other and to seeing that this will not cause problems among them" (Pepetela 20I3, II3). And the Commissioner responds:

- It was a thoughtless gesture, it's wrong. The criticism should be made in a Command meeting or in private. That's the way it's always been said.

- That's where the evil lies - said Sem Medo. - Things are going on among those responsible. If there's dirty laundry to be washed, the militant must not know, it's taken in the little chapel. (...) How then do you teach the guerrilla fighters to criticize and be sincere, and to control those responsible, if in practice you don't give them examples? (Pepetela 20I3, II3).

4 In the early years of independent Angola, the MPLA, a movement that came out ahead in building a national image for the newly created Angolan state, began to defend the emergence of the new man, who should not be attached to ethnic, tribal, and/or religious conceptions. The traditional was now seen as negative, the developmentalism of the new nation should be linked to a rupture with ethnicity, regionalism, racism, and religions. Tradition and modernity appeared as extreme poles and a problem to be overcome (Bittencourt 20I0). 
Pepetela's comparison of a party to a chapel in the course of the debate points to the silences surrounding the MPLA's internal relations. From this passage one may note the restriction of political freedoms, denying the right to difference, pluralism and democracy, without even respecting the individual. These practices contributed to the strengthening of an authoritarian and unequal policy. This reference will appear in other moments of the novel, as well as in the novel A Geração da Utopias (1992). Therefore, the "religiosity" of the political project proposes, in this sense, to make reference to the creation of a Party linked to a truth that is absolute and intolerant of differences (Mata I993, 267). When asked about the constant association between socialist theory and the Catholic Church in his novels, Pepetela answers:

It is very curious that the structure of the Catholic Church is so similar, although with different names, to the structure of the Communist Parties (the synod of cardinals and the central committee, the infallibility of the leader, the Councils on one side, the congresses on the other, etc.). Of course, about the One Truth, or One True Religion, and the one true theory of society, often falling into totalitarianism and the most fundamentalist intransigence, there are also strange similarities. Marx has a phrase (I don't have it in mind so I can only give the idea and not the quote) in which he declared himself fascinated by the religious that was contained in politics (Pepetela, In: Minuzzi 20I7).

These notes reflect the lack of consensus on socialist theory among MPLA members. There has always been a tension, which at times has had repercussions in ruptures and withdrawals among the militants of the Movement. Reading Pepetela's novels we can follow the different relations that have been established between the men of the party, as well as between society and socialism, the representations of these relations go back to accommodations of interests that were ambiguous. As Nuno Vidal (20I6) explains, we can identify within the MPLA the existence of a progressive socialist wing, led by public men of great importance to the Movement, such as Lúcio Lara, Carlos Dilowa, Iko Carreira, and Antônio Jacinto, defenders of Marxist socialism that exalted a revolutionary ideological position, and another group, with which they disputed space, who defended a more flexible economic policy and, incredulous of Marxist socialism, defended "a system of nationalist leadership" that was in dialogue with the culture and tradition of the country.

We can highlight in this last wingmen like Agostinho Mendes de Carvalho, Domingos Paiva da Silva and Manuel Pacavira. This institutional bipolarity will be very well articulated by Agostinho Neto who will put into

5 The Generation of Utopia, in free translation. 
operation "a system of management of balances of power based on the rotation of appointments to the top positions in the party and state" (Vidal 2016). The political interests of the system were thus assured and were controlled by Neto in a pragmatic way, forming a "patrimonial carousel of positions". It is also important to emphasize how much this division carries with it the racial issue. While the first group was formed mainly by whites and half-breeds and had a relatively higher level of educational instruction, the second was made up of a black M bundu base (Vidal 20I6).

Therefore, it is interesting to know this scenario in order to understand the political disputes that were part of the writing of Pepetela (20I7). The writer puts himself as an advocate of freedom, equality and the values of individuals, but at the same time, he was in favor of a socialist political structure, which, as he has said a few times, would be close to a utopian socialism, because he was very critical of the way socialism was raised and defended in other already independent African states. At that moment the choices for the political future of the country were at stake, and criticism of the authoritarian construction of a single model party worried the writer, who already seemed non-conformed, even by reserving a final destiny for Sem Medo, the hero of Mayombe. On the other hand, we are reminded how much Pepetela (20I7), as an agent of the Angolan state after independence, also contributed to the strengthening and legitimization of the political model that was formed. If the interviews, given after his departure from the party, point to discontent with an authoritarian political structure, and his novels published in the I980 pointed to the inevitability of this reality, it is strange that he remained in the MPLA until I982, even contributing directly to the fight against the Nitista Movement (I977).

Returning to Mayombe, the characterization of a political scenario where there are no political alternatives is reaffirmed. The Movement's internal mistakes are pointed out, but within a reflection that distinguishes the MPLA as the only viable alternative to the other nationalist movements, stuck to tribal and racial issues. For the writer, the process of narrating the humanization of the guerrilla fighter and the leader, as individuals who make wrong and right choices seems fundamental to broaden the debate on the political, although only in the internal aspect of the MPLA. Thus, he advocates the development of a more democratic political and social structure in which differences could open space for the formation of a democratic political environment where criticism would be possible and would help build a more inclusive society. In that same debate, Sem Medo continues: “- You all talk so much about the popular masses and want to hide everything from the people" (Pepetela 20I3, I09). By always referring to "you all" at the beginning 
of his sentences, Sem Medo is questioned again by the Commissioner, who is annoyed that he is part of this plurality. But the commander fights back:

- Because you are really part of a group: the future Party officials, the senior officials, who are going to release the ex-communication on heretics like me. "You all" represent all those who have no humor, who take themselves seriously and show ominous looks of occasion to give themselves importance (Pepetela 2013, I09).

Sem Medo then refers to the end of the war and begins to narrate what it would be like from the moment the MPLA, as a victorious party, came to power. As long as the opposition was not allowed, for the consolidation of the independence process, Angola would live in a dictatorship, not of the proletariat, but of a "small group of men" who would be on a fine line between a power that represented the people and the human ambitions that could speak louder and destroy the dreamed political project. The disillusionment with this group would happen "when they realized that in practice socialism is not the work of a day or the will of a thousand men," and new challenges would arise for the Party, which would be increasingly forced to close down and persecute those who criticized it:

And how will you react? The people are being agitated by counter-revolutionary elements! This will also be true because any regime creates its opposition elements, we have to arrest the leaders, we have to pay attention to the maneuvers of imperialism, we have to strengthen the secret police, etc., etc. The dramatic thing is that you will be right. Objectively, it will be necessary to tighten the vigilance inside the Party, increase discipline, clean up. Objectively, this is how it is. But these cleanings will serve as a pretext for ambitious men to mix up counterrevolutionaries with those who criticize their ambition and their mistakes. The necessary vigilance within the Party will pass to the police environment within the Party and all criticism will be stifled within it. Centralism is strengthened, democracy disappears. The dramatic thing is that there is no escape from that... (Pepetela 20I3, III).

It is interesting in this passage to note that as the political project consolidates, we witness the departure of Sem Medo from the group that will make up the country's future leaders, as he announces to the Commissioner: “- I see you clearly, as a political cadre. As to me, I do not see myself. Perhaps in another country in the struggle... Who knows if in jail? I don't see myself in independent Angola" (Pepetela 20I3, II5). For him, "the political cadres of the Movement" (Pepetela 2013, IIo) would be linked to Marxism, which he 
also approached, but he also distanced himself by not agreeing with "a series of things that are said or imposed, in the name of Marxism", so he considers himself an "anarchist, a non-Party, a renegade" (Pepetela 20I3, IIO), who won't have space in the political plans of the movement. This "series of things" is soon shown, while the character moves away for a few moments from the authoritarian political structure that is already outlined during the war and that will establish itself in the post-independence. Among the dialogues that appear at this particular moment in the narrative, we note the political uncertainties regarding the socialist position of the MPLA, which for Sem Medo would be forced:

Let us not call that socialism, because it is not necessarily. Let's not call it a proletarian state, because it's not. Let's demystify the names. Let's put an end to the witchcraft of labels. It is not a democracy, because there will be no democracy, there will necessarily be a dictatorship over the people (Pepetela 20I3, II3).

From these passages, we can notice, during the moment of Mayombe's writing, his disillusionment with the authoritarian directions that were taking the MPLA. This made him anticipate the political scenario that was to come. However, it is worth highlighting again Pepetela's participation in the MPLA's governmental structure that was established after independence, even being part of one of the most repressive moments of the regime. If the character of Sem Medo would be reserved an end that would keep him forever on the side of revolutionary ideas, keeping him away from the political system that was established, which for the writer would lead to a corrupt and authoritarian system, Pepetela will act in the state until i982.

As we turn again to the political-ideological debates held at that time, we can notice the uncertainties and ambiguities already present within the Movement, including by its leaders. The MPLA, guided by an integrationist and globalizing discourse, was recognized before independence by the defense of nationalism, in a broad narrative that had in common the struggle for independence and the construction of a pluricultural nation. In this sense, it denied the racial and ethnic differences that could be impediments to its objective. However, as much as the Movement's program could be seen from the point of view of "revolutionary nationalism", as Mabeko-Tali points out, in recognizing the desire to "profoundly transform the economic and social structures created by the colonial system", we must not forget the great diversity of people and ideas that make up the MPLA, each with a different 
vision of the future of Angolan society (Mabeko-Tali 200I, I52-160). Therefore, the defense of a Marxist-Leninist political structure was not unanimity.

Many of the MPLA's political cadres have indeed placed themselves on the side of Marxism, but within an international context of Cold War that should not be diminished. At the time of the guerrilla war, this relation was even more modest, built between rapprochements and estrangements according to the political interests at stake. Moreover, the political program of the MPLA was never clear, as we can notice in some interviews and speeches from Agostinho Neto. When asked about the ideological option of the MPLA, Neto answers:

There are schematic descriptions, used to classify the movements as communist, socialist, etc. But we think that, in our movement, such classification is not possible at this stage. For a simple party, it is possible, but when a movement is made up of politically and ideologically different peoples it is not possible, for example, to say that it is communist [...]. Concerning economic organization, we say that the Angolan people should be masters of our country's riches, that fair wages are needed to avoid the exploitation of workers, etc. is what is usually called socialist. It is socialism, because we do not intend to allow anyone, Angolan or foreign, to exploit our people. (Neto, In.: Mabeko-Tali 200I).

Statements like this were successive until the Party's adopted the Marxism-Leninism in I977. Until then, both Agostinho Neto and other comrades of his sought to dissociate themselves from the labels attributed to him by political opponents. Thus, when Pepetela addresses this debate in his novel, he helps us to reflect on the complexities of the political cultures that were in force at that time. By observing different characters, the contradictions and ambiguities that would form the political structure of the MPLA in the post-independence period appear. Sem Medo wants to avoid labels emphasized by others, even when they do not contribute to the strengthening of the guerrilla movement. From him also comes criticism about the socialist nature of the Movement, which for the writer is fragile and "populist", because social inequalities would remain while the people were still on the fringes of political power, and the experience of other African revolutionary movements led him to believe that the path of politics in Angola was going in the same direction. At this moment, we realize how much Mayombe's writing already showed a discredit as to the future of the MPLA, as much as Pepetela did not break with the Movement together with those who participated in the Revolt of the East and the Active Revolt. When asked when he began to 
notice that the independence project in which he believed began to become a utopia, he answered:

I never thought nor was it ever a utopia, that is why we gained independence. But the project of many was not only that, but it was also to create a fairer society, and that has not yet been achieved. My book "Mayombe", written in I970-7I shows that I was already beginning to moderate that hope (Pepetela. In: Minuzzi 20I7).

In one of the dialogues between Sem Medo and the Commissioner, the Commander states that the dictatorship may be necessary, he is not sure, but he cannot think of any other way, even if it is not ideal and then says: "Let us be honest with ourselves. We are not going to get to one hundred percent, we are going to stay at fifty. Why then tell the people we're going to go to the hundred percent?" This position was taken by Pepetela already demonstrates how much the dream of a totally free society is staying on the path, through the years of guerrilla warfare.

In this sense, the Angolan political system was born without a precise debate on "democracy" and "popular power", one of the main demands of the political oppositions that arose in I974, "which accused democratic principles of betrayal" by emphasizing authoritarianism and the concentration of power in Neto's hands. And as we can see, these debates are already echoed in Mayombe, through the lines of Sem Medo. It is certainly a moment of intense reflection on the political directions of the movement and we can notice, in the pages of the novel, how much Pepetela participates and contributes to this debate, already existing in the early I970s and heated in the I980s, when socialism is no longer seen as the best solution.

Sem Medo is described as the great hero of Mayombe, from a close narrative choice in which he will be used to heroize the character Aníbal in A Geração da Utopia, that is, the heroization occurs as they are put aside from the political process that is established during and after the war. When he calls himself a "heretic," we can notice the difficulties that Sem Medo would have in being part of the political apparatus and the state bureaucracy, which although he thought necessary for the affirmation of the Movement, he could not recognize himself within this gear, which would bring him closer to a utopian character, more developed by Pepetela through Aníbal. As Alexandra Santos states, we have witnessed the "impossibility of the apparatus of power coexisting with the individualism and critical spirit personified in Sem Medo" (Santos 20II, 84). Possibly, if he remained alive until the MPLA took power, he would be 
removed and break with the government, from some opposition movement or even having his destiny close to the character Aníbal of A Geração da Utopia.

Within this debate, it is interesting to note how Sem Medo refuses to be "dogmatic", in the strict sense of the term, by opening himself up to questions and uncertainties and denying the absolute truth of things. For him, the definition of dogmatism is in being:

Rigid in his conception of the discipline, he does not see the conditions that exist, he wants to apply the scheme as he has learned it. That's what I call dogmatic, I think it is the true meaning of the word. His truth is absolute and all made up, he refuses to put it into doubt, even if it were to be discussed and then reinforced with the data of practice. Like those Catholics who refuse to question God, because that could disturb them (Pepetela 2013, I59).

As we turn to this passage, the distance that Sem Medo will take from the political power that he thinks will be established after independence becomes understandable, since there will be no room for opposition, criticism and doubts. To live in this state would be unfeasible for the character who defines himself as a libertarian, sometimes approaching anarchism and at other times flirting with communism. For this reason, he is creating new political conceptions that guide him, which do not necessarily fit the labels already given. One example is how the writer defines what it means to be communist, within a perspective of freedom. By characterizing a French friend of his, according to Sem Medo, a "true libertine", the term communist was appropriate, but not in the "classical, orthodox, sense of the word, but in my sense" (Pepetela 2013, I92). And Ondina, a key character in the narrative ${ }^{6}$, asks him:

- In which women are collective?

- What are those ideas? That's anti-communist Catholic propaganda. For him, every woman should be free to accept him or refuse him, just as he was free to desire any woman or not. That's all. And if there were consequences, everyone was free to bear them. He was a communist, not in the sense that women are collective, but in that they are as free as free men (Pepetela 2013, I92-193).

6 Through this character we are involved in new themes that enable the questioning of the role of women within the process of liberation struggles, as well as the constructions of Pepetela on the role of women and their ideals of freedom that would challenge the taboos of society and individual morality, guided by social morality that differentiates men and women in their pleasures and duties. 
We can see that through these debates new perceptions of Angolan society are opening up. Sem Medo, as a character, refuses to be part of the project of a society that is unequal, both between men and women, and among other barriers that would delimit and frame men, as the racial and/or ethnic factor. This position would tend to lead him to the step away from the MPLA after independence, because the loss of some initial values to remain in power would be inevitable and the character from beginning to end is aware of this movement, as clarified in a passage at the end of the book. In a dialogue with Mundo Novo, one of the guerrilla fighters, Sem Medo affirms:

You are the apparatus type of guy, one of the ones who is going to install the sole and omnipotent Party in Angola. I'm the guy whose historical role ends when we win the war. But my goal is the same as yours. And I know that to achieve my goal, an intermediate phase is necessary. Guys like you will fill that intermediate phase. So I think I was right to support your name. One day, in Angola, there will be no need for rigid apparatuses, that's my goal. But I won't get there (Pepetela 20I3, 227).

Pepetela's novels are characterized by keeping this thread of hope and optimism at the end, which we can see in Mayombe, using the highlighted passage. However much of what the writer points out as the internal problems that already present themselves as a barrier to the ideal of society he defends, especially as he defends men in their individuality by recognizing the guerrilla fighters as "a set of different, individual beings, each with their own subjective reasons for fighting and who, in fact, behave as such". This position emphasizes the contradictions and ambiguities that exist between Sem Medo and the MPLA, because for him a new man is also born when "a young man decides to build himself a personality, even if this politically means individualism" and in practice goes against the project of a socialist society. For this position, Sem Medo says he cannot belong to a state apparatus, because that would limit him.

On the other hand, at the same time, Pepetela, between the narrative voice of his characters, also defends and exalts the emergence of a New Man in the principles that the MPLA highlights. When narrating an action that occurred under the support of a great number of men, Commander Sem Medo says:

That's why I trust Angolans. They're Confucians, but everyone forgets the makas and the grudges to save a fellow man in danger. That's the merit of the Movement, having achieved the miracle of beginning 
to transform men. One more generation and the Angolan will be a new man. What is needed is action (Pepetela 2013, 203).

This degree of solidarity that for the Commander would be innate to Angolans is what would put an end to the differences that would be an impediment to the construction of a nation and an Angolan state after independence. Therefore, if we understand the importance of ethnic and "tribal" factors for the construction of a nationalist project, it is important to stress here how much the defense of a national project defended in the pages of Mayombe was linked to the MPLA's power project. In this sense, as Alexandra Santos points out, the adjective "tribal", used throughout the work, to characterize the existence of various social groups in Angola seeks to disqualify and devalue the existing differences by "suggesting a primitive and rudimentary form of social organization" (Santos 20II, 6I). In dialogue with this play Sem Medo, the main character and the great hero of the novel, keeps himself away from these ethnic debates that were frequent among the guerrilla fighters.

As we turn to the narrated history of militant André, we can perceive the degree of distance and closeness to the frequent political debates of the period. André was one of the leaders of the guerrilla military base and of Kikongo origin, unlike Ondina, with whom he had an affair, who was the girlfriend of the political Commissioner, a Kimbundu. These characteristics would not be important for Sem Medo, however, the conflicts that ethnic origin still generated within the movement made him reflect on this case. André was no longer very favored by the great majority of the guerrilla fighters, since he was responsible for the food that was missing, and it is also through him that we know the favors that already existed among the militants, since it was known that he gave money on the sly to men close to him when they arrived in Dolosie. Therefore, it is precisely because he is a character with a dubious character that he approaches and identifies with tribal issues, with class differences and with the permanence of clientelism in current politics:

The plebs are all the same, they do not deserve trust, the one responsible for them is only worthwhile they can bring benefits to them. That's why my father, who was Soba, spent so much money to distribute to his men. He knew that if he didn't, he would lose his strength. My mistake was to forget those elementary teachings.

Deep down, deep down, it's Sem Medo who's going to get screwed. I'll go somewhere else where I'll go up anyway: there's such a lack of cadres that who has one eye is king. He will be here with all the problems, now aggravated. Sem Medo is just a little wolf, I'm an experienced wolf, I know what I mean (Pepetela 20I3, I70-I7I). 
The passage above refers to the moment when André is caught by the other militants to be tried for his crime of treason for having gone to bed with the Commissioner's wife. We understand from his speech that regardless of the political model that is established in Angola, men like André will always have space and privileges, remaining in political power. It is these findings that will lead Sem Medo to gradually move away, placing himself as a utopian before the political inevitability, including the fact that corruption is narrated as a problem that affects all men:

The traitors stopped the fight from growing. Traitors on all sides. It is a lie to say it is the Kikongos or the Kimbundus or the Umbundos or the Mulatos who are the traitors. I've seen them of all languages and colors. I saw our own countrymen who had farms want to take advantage to increase the farms. And some collaborated with Pide (Pepetela 2013, I85).

In addition, within this political framework outlined by Pepetela, we also noticed the disfavor of other groups that were involved in the guerrilla war for independence, such as the UPA (Union of the Populations of Angola) and the FNLA (National Liberation Front of Angola), linked to ethnic conceptions and therefore diminished in the political dispute. The MPLA appears throughout the book as a movement of all, while the UPA appears only linked to the I96I massacre, as a disorganized and primitive group. When one of the militants, the head of operations, is called to the narrative, he presents himself as the son of a peasant compared to Sem Medo and the Commissioner, intellectuals who brought him the "meaning of the words" about the attacks on the settlers' fields in which he participated. With distancing and knowledge, now on the MPLA's side, the Chief of Operations states:

I came to the Congo and in the MPLA I learned how to make war, a war with the organization. I also learned to read. Above all, I learned that what we did in I96I, cutting off the heads of the white, half-breed, assimilated and umbundus, was perhaps fair at that moment. But today it can't be a source of pride for anyone. It was a historical necessity, as the Political Commissioner says. I understand the meaning of the words, he is right, in that he is right (Pepetela 2013, 209). 


\section{Conclusion}

In that sense, we have the legitimization of the MPLA, exalted in the pages of Mayombe as a great guide to an independent Angola. As much as the problems existed, such as the favoritism policies, the disputes between the intellectuals, as well as the escalation between the urban man and the peasant, and some of them could still persist in the post-independence, following the MPLA is seen as the only possible path. The struggle against the colonizer must be inseparable from this project. For this reason, Alexandra Santos argues that “all of Sem Medo's discourse is crossed by the inability to imagine alternative futures as if there were no option as to the imposition of an authoritarian regime in Angola" (2OII, IOI).

It is also interesting to note how this discourse is supported by a broader debate, in which it points to the complex rapprochement between society and the state in the post-colonial era. In affirming that the advance of independence implied the "concentration of authority and not the dissipation of forces", denying a democratic ideology, Augusto Nascimento, in an analysis of political relations in São Tomé and Príncipe after the country's independence, calls attention to the diffusion of excusable ideas to justify the new forms of domination that were imposed by parties within a single-party system. Also, the abstention of some intellectuals in this debate contributed to reducing the political, since the development and modernization of the state would necessarily be linked to authoritarian practices in the face of a delicate historical moment in which the main enemy continued to be the other, sometimes represented by the colonizer, and sometimes represented by the other opposition nationalist fronts, when it was convenient (Nascimento 2010, I60).

Through the discourses in Pepetela's narratives, we can learn a little about the tensions surrounding the political debates of the period in which the novels were written. In Mayombe, the intellectual, still very close to the MPLA, legitimizes the political choices of the movement, which would be restricted to him, given the needs imposed by the historical period. However, if in $O$ Cão e os Caluandas ${ }^{7}$ we already see a narrative that denounces the cases of corruption and clientelism that have established themselves as a political model in the country, it is after Geração da Utopia that it becomes clear how much the political project dreamed of in the guerrilla era is no longer a possible path within a political structure that has already been ruined. However, it is still interesting to note how much Pepetela recreates this political

7 The Dog and the Caluandas, in free translations. 
panorama, showing the greed of predatory men, but also the permanence of utopia in some characters who appear more and more distant from the political regime that was established in the post-independence.

It is still worth underlining how the state in the Mayombe period is the colonial state and how we can already observe that amid the chaos of the guerrilla warfare, micropolitics that are autonomous to the power of this state are already developing. These have to do with an internal logic of their own, based on factors that move the political in Angolan society and will contribute to the complexities that surrounded the formation of the post-colonial state.

\section{References}

Antunes, Gomes Catarina. De como o poder se produz: Angola e as suas transições. 2009. Coimbra. Tese de Doutoramento em Sociologia. Faculdade de Economia/ Universidade de Coimbra

Bittencourt, Marcelo. Angola: Tradição, modernidade e Cultura política. 20ıo In: Reis, Daniel Aarão; Mattos, Hebe; Oliveira, João Pacheco; Moraeus, Luís Edmundo de Souza Moraes; Ridenti, Marcelo (org). Tradições e modernidades. Rio de Janeiro: Editora FGV

Bittencourt, Marcelo. Nacionalismo, Estado e Guerra em Angola. 20I5 In.: Ferreras, Norberto O. (Org.) A questão nacional e as tradições nacional-estatistas no Brasil, América Latina e África. Rio de Janeiro: FGV

Mabeko-Tali. Dissidências e poder de Estado. 200I. O MPLA perante si próprio. (I962-I977), V.2. Luanda:Nzila

Maria, Adolfo, Entrevista concedida a Fabio Baqueiro Figueiredo, Lisboa, 9 fev. 20II.I In.: Figueiredo, Fábio B. 20I2. Entre raças, tribos e nações: Os intelectuais do Centro de Estudos Angolanos. Tese (doutorado) Universidade Federal da Bahia, Faculdade de Filosofia e Ciências Humanas, Programa Multidisciplinar de Pós-Graduação em Estudos Étnicos e Africanos, 2012.

Pepetela. Entrevista concedida a Luara Pinto Minuzzi. 20I7. Em Navegações. v. Io, n. I, p. 84-96, jan.-jun

. Mayombe. 2013. São Paulo: Leya

. Geração da Utopia. 2oıza. São Paulo: Leya

Santos, Alexandra Dias. Nação, Guerra e Utopia em Pepetela (1971-1996). 20II. Tese de doutorado apresentada no Instituto de Ciências Sociais da Universidade de Lisboa 
Vidal, Nuno. O MPLA e a governação: entre internacionalismo progressista marxista e pragmatismo liberal-nacionalista. 2016 In.: Estudos Ibero-Americanos, Porto Alegre, v. 42, nº 3, p. 815-854, set-dez

\begin{abstract}
After the independence of Angola in I975, a political structure was consolidated in which the state/MPLA became the main means for the distribution of benefits and privileges, contributing to the strengthening of an authoritarian and patrimonial policy. Therefore, this article aims to start from the novel Mayombe (I980), by the Angolan writer Pepetela, to analyze the political process in Angola in its contemporaneity. It is understood that the power structures that existed in Angola after independence, appear already drawn in this novel, still woven in the guerrillas. In the same way, there are debates about the nation and identity propagated in the midst of the Popular Movement for the Liberation of Angola (MPLA). It is assumed that the contradictions, ambivalences, and accommodation of interests present between Angolan society and the state were already being structured internally even before independence.
\end{abstract}

\title{
KEYWORDS
}

Pepetela; Angola; Mayombe.

Received on February 11, 2020

Accepted on March 15, 2020

Translated by Artur Holzschuh Frantz 